\title{
Characteristics of Inclusions in Low Carbon Al-Killed Steel during Ladle Furnace Refining and Calcium Treatment
}

\author{
Wen YANG ${ }^{1,2,3)}$ Lifeng ZHANG ${ }^{1,2) *}$ Xinhua WANG ${ }^{2)}$ Ying REN ${ }^{2)}$ Xuefeng LIU $^{3)}$ and Qinglin SHAN ${ }^{4)}$ \\ 1) State Key Lab. of Advanced Metallurgy, University of Science and Technology Beijing (USTB), Beijing, 100083 China. \\ 2) School of Ecological and Metallurgical Engineering, USTB, Beijing, 100083 China. \\ 3) School of Material Science and Engineering, USTB, Beijing, 100083 China. \\ 4) Steelmaking Department of Shougang Jingtang United Iron \& Steel Co., Ltd, Tangshan, 063200 China.
}

(Received on February 6, 2013; accepted on April 30, 2013)

\begin{abstract}
A plant trial of the productions of LCAK steel was performed, and characteristics of inclusions during LF refining and calcium treatment were investigated. Besides, thermodynamic diagram among magnesium, aluminum, and oxygen as well as calcium, magnesium, aluminum, and oxygen in the steel melt were studied to understand the fundamentals of inclusion modification by calcium treatment in LCAK steel. Furthermore, the change mechanisms of oxide inclusions and the precipitation of calcium sulfide were discussed. The experimental results showed that oxide inclusions were partly changed along with the path of $\mathrm{Al}_{2} \mathrm{O}_{3} \rightarrow \mathrm{MgO} \cdot \mathrm{Al}_{2} \mathrm{O}_{3} \rightarrow(\mathrm{MgO} \cdot) \mathrm{CaO} \cdot \mathrm{Al}_{2} \mathrm{O}_{3}$, which was a little different from the thermodynamic calculation results due to the limited kinetic conditions. Calcium treatment somehow modified the inclusions, however, many large inclusions were generated, and the modification effect would be dramatically decreased by the formation of large amount of CaS inclusions, which appeared with three main distribution forms. The formation of inclusions after calcium treatment were discussed based on the thermodynamic analysis. In order to reach the target of modification, sulfur concertration in steel should be reduced to a small amount to decrease the formation of CaS.
\end{abstract}

KEY WORDS: LCAK steel; ladle furnace refining; calcium treatment; calcium aluminate; CaS.

\section{Introduction}

Low Carbon Aluminum Killed (LCAK for short) steel is well used to produce cold rolled sheets for automobiles, family appliances, etc. Thus, the quantity, size, morphology, and distribution of inclusions need to be well controlled.

As secondary refining approaches for LCAK steel, ladle treatment with gas stirring, CAS or RH refining are well used, and many relevant studies on steel cleanliness during these refining processes have been reported. ${ }^{1-7)}$ Recent years, ladle furnace (LF) refining is also chosen to produce LCAK steels, especially for thin slab casting processes. ${ }^{8,9)}$ To prevent the breakout during thin slab continuous casting process, the sulfur content in steel need to be relatively low. Thus desulfurization is needed during secondary refining process. For thin slab casting process, calcium treatment is needed to prevent nozzle clogging, and LF refining is good to perform calcium treatment. During LF refining, high basicity and low $\mathrm{Fe}_{\mathrm{t}} \mathrm{O}$ content slag are used to prevent [Si] pickup and guarantee stable $\mathrm{Ca}$ treatment. The temperature fluctuation and temperature drop are also small compare to the refining processes of $\mathrm{RH}$ and CAS.

In the current study, the characteristics of inclusions in a LCAK steel produced by "BOF $\rightarrow \mathrm{LF} \rightarrow$ Calcium treatment $\rightarrow$ Continuous casting (CC)" process are investigated. The composition, amount, size distribution, morphology and formation mechanism are discussed.

* Corresponding author: E-mail: zhanglifeng@ustb.edu.cn DOI: http://dx.doi.org/10.2355/isijinternational.53.1401

\section{Experimental and Analysis Methodology}

Industrial trials for the production of two heats LCAK steel were performed in $300 \mathrm{t}$ ladles with magnesia carbon lining. The production route is " $\mathrm{BOF} \rightarrow \mathrm{LF} \rightarrow$ Calcium treatment $\rightarrow$ CC". During tapping of BOF, a certain amount of aluminum was added into the molten steel to decrease the dissolved oxygen to several ppm. Approximately $1500 \mathrm{~kg}$ synthetic slag was added into the ladle during tapping to reduce $\mathrm{FeO}$ and $\mathrm{MnO}$ in the slag to less than $1 \%$. During LF refining high basicity slag (approximately $2500 \mathrm{~kg}$ ) was used and aluminum was added to improve the deoxidation. After the refining, $570 \mathrm{~kg}$ and $418 \mathrm{~kg} \mathrm{Ca}-\mathrm{Fe}$ wire were added for Heat 1 and 2 respectively.

Steel and slag samples were taken before LF refining, at the earlier stage, the middle stage, and the end of LF refining, after Ca treatment, and after soft blowing for two heats. Since the entire refining time of the two heats is different from each other, for the two heats, samples were not taken at the exactly same time, but at the same refining stages.

The contents of $\mathrm{C}, \mathrm{S}$ and total oxygen (T.O.) of the steel samples were analyzed using infrared analysis. The concentrations of calcium, magnesium, silicon, manganese and the dissolved aluminum were analyzed using ICP-AES. The nitrogen content was analyzed using thermal conductance method. The slag composition was analyzed using fluorescence analysis.

Inclusions on the cross-sectional of each steel sample were detected using automated SEM/EDS inclusion analysis (ASPEX). ASPEX is a computer-controlled scanning electron microscope that is designed for the automated imaging 
and elemental analysis of a wide spectrum of surfaces and particulates. The system provides a fully integrated SEM and EDX platform for addressing the micro-scale visualization needs. It can simultaneously detect the size, shape, area, number, location and elemental composition of inclusions in steel samples. Rotary Chord Algorithm (RCA) is used to determine the characteristics. After the center of a inclusion is found, 16 chords are drawn through the center with interval of $11^{\circ}$. Based on the size combination of the chords, the shape and size (including the maximum diameter, the minimum diameter and the average diameter) of the inclusion can be determined. In the current work, the working magnification was set at $\times 225$ and the minimum detectable inclusion is $\sim 1.0 \mu \mathrm{m}$, and the maximum diameter was chosen as the size of inclusion.

Two statistical parameters, area fraction and number density, are defined as the following two equations to characterize non-metallic inclusions.

$$
A F=\frac{A_{\text {inclusion }}}{A_{\text {total }}}
$$

where, $A F$ is the area fraction of inclusions, $\mathrm{ppm} ; A_{\text {inclusion }}$ is the total area of the detected inclusions, $\mu \mathrm{m}^{2}$; and $A_{\text {total }}$ is the area scanned, $\mathrm{mm}^{2}$.

$$
N D=\frac{n}{A_{\text {total }}}
$$

where, $N D$ is the number density of inclusions, per $\mathrm{mm}^{2}$; and $n$ is number of detected inclusions on the area of $A_{\text {total }}$.

\section{Results}

\subsection{Variation of Steel and Slag Compositions}

The chemical compositions of slag and molten steel samples are listed in Tables $\mathbf{1}$ and $\mathbf{2}$ respectively. The dissolved oxygen content of the steel measured by oxygen probes before LF refining of the two heats was $0.0007 \%$ and $0.0051 \%$ respectively. Table 1 shows that the slag basicity is high after the addition of synthetic slag in LF refining process especially for the second heat, which is benefit for desulfurization of the molten steel and reducing $\mathrm{FeO}$ and $\mathrm{MnO}$ in the slag. The variation of sulfur content in steel and sulfur distribution ratio (defined as $\left.\mathrm{L}_{\mathrm{S}}=(\% \mathrm{~S}) /[\% \mathrm{~S}]\right)$ is presented in Fig. 1.

\begin{tabular}{|c|c|c|c|c|c|c|c|c|}
\hline $\begin{array}{l}\text { Heat } \\
\text { No. }\end{array}$ & Process & $\mathrm{SiO}_{2}$ & $\mathrm{Al}_{2} \mathrm{O}_{3}$ & $\mathrm{CaO}$ & $\mathrm{MgO}$ & $\mathrm{S}$ & $\begin{array}{l}\mathrm{CaO} / \\
\mathrm{SiO}_{2}\end{array}$ & $\begin{array}{l}\text { T.Fe } \\
+\mathrm{MnO}\end{array}$ \\
\hline \multirow{6}{*}{1} & BOF End & 10.97 & 1.86 & 37.13 & 8.61 & & 3.38 & 29.60 \\
\hline & $\mathrm{LF} 4 \mathrm{~min}$ & 10.78 & 25.79 & 37.90 & 7.70 & 0.020 & 3.52 & 8.69 \\
\hline & $\mathrm{LF} 15 \mathrm{~min}$ & 8.24 & 22.75 & 51.88 & 6.52 & 0.056 & 6.30 & 2.24 \\
\hline & LF 29 min & 8.81 & 23.07 & 51.47 & 7.08 & 0.056 & 5.84 & 1.24 \\
\hline & $\begin{array}{l}\text { Soft blowing } \\
3 \text { min after } \mathrm{Ca}\end{array}$ & 9.88 & 26.02 & 48.89 & 6.27 & 0.104 & 4.95 & 0.89 \\
\hline & $\begin{array}{l}\text { Soft blowing } \\
13 \text { min after } \mathrm{Ca}\end{array}$ & 11.41 & 21.99 & 49.97 & 6.20 & 0.112 & 4.38 & 0.90 \\
\hline \multirow{7}{*}{2} & BOF End & 13.74 & 2.02 & 45.91 & 8.64 & & 3.34 & 20.03 \\
\hline & LF $3 \mathrm{~min}$ & 7.19 & 19.82 & 54.22 & 5.23 & 0.028 & 7.54 & 3.64 \\
\hline & LF $14 \mathrm{~min}$ & 7.66 & 18.82 & 54.27 & 5.03 & 0.028 & 7.08 & 3.85 \\
\hline & $\mathrm{LF} 25 \mathrm{~min}$ & 7.13 & 19.41 & 55.98 & 5.73 & 0.036 & 7.85 & 2.63 \\
\hline & LF $35 \mathrm{~min}$ & 6.80 & 19.97 & 53.13 & 5.53 & 0.048 & 7.81 & 4.28 \\
\hline & $\begin{array}{l}\text { After } \mathrm{Ca}-\mathrm{Fe} \\
\text { wire injection }\end{array}$ & 5.79 & 21.57 & 57.16 & 6.24 & 0.048 & 9.87 & 0.80 \\
\hline & $\begin{array}{l}\text { Soft blowing } \\
9 \text { min after } \mathrm{Ca}\end{array}$ & 5.26 & 23.55 & 55.31 & 6.21 & 0.052 & 10.52 & 1.30 \\
\hline
\end{tabular}

Table 1. Composition of slags at different steps (wt $\%)$.
Table 2 and Fig. 1 indicate that the sulfur content decreased significantly with increasing refining time, and the second heat had lower sulfur content. Before calcium treatment, the sulfur content is $0.0074 \%$ for the first heat and is $0.0040 \%$ for the second one. A higher initial sulfur may be owing to more carry-over of the BOF during tapping. The variation of sulfur distribution ratio of the two heats is almost the same no matter the big difference of the initial sulfur content.

By adding synthetic slag and aluminum to the slag, the content of (T.Fe $+\mathrm{MnO})$ in slag was decreased to $<1.5 \%$ at the end of LF refining, which ensures the stable subsequant $\mathrm{Ca}$ treatment and prevent the reoxidation of the dissolved aluminum into alumina by $\mathrm{FeO}$ and $\mathrm{MnO}$ in the slag.

\begin{tabular}{|c|c|c|c|c|c|c|c|c|c|}
\hline $\begin{array}{l}\text { Heat } \\
\text { No. }\end{array}$ & Process & $\mathrm{C}$ & $\mathrm{Si}$ & Mn & $\mathrm{P}$ & S & T.Ca & T.Mg & $\mathrm{Al}_{\text {sol }}$ \\
\hline \multirow{5}{*}{1} & $\mathrm{LF} 4 \mathrm{~min}$ & 0.042 & 0.016 & 0.19 & 0.0082 & 0.0130 & 0.0007 & 0.0003 & 0.019 \\
\hline & $\mathrm{LF} 15 \mathrm{~min}$ & & & & & 0.0098 & 0.0003 & 0.0003 & 0.015 \\
\hline & LF $29 \mathrm{~min}$ & 0.039 & 0.014 & 0.21 & 0.0102 & 0.0074 & 0.0004 & 0.0003 & 0.045 \\
\hline & $\begin{array}{c}\text { Soft blowing } \\
3 \mathrm{~min} \\
\text { after } \mathrm{Ca}\end{array}$ & & & & & 0.0062 & 0.0037 & 0.0007 & 0.036 \\
\hline & $\begin{array}{c}\text { Soft blowing } \\
13 \mathrm{~min} \\
\text { after } \mathrm{Ca}\end{array}$ & 0.041 & 0.029 & 0.21 & 0.0102 & 0.0058 & 0.0031 & 0.0005 & 0.036 \\
\hline \multirow{6}{*}{, } & LF $3 \mathrm{~min}$ & 0.039 & 0.001 & 0.17 & 0.0076 & 0.0063 & 0.0008 & 0.0004 & 0.0018 \\
\hline & LF $14 \mathrm{~min}$ & & & & & 0.0058 & 0.0004 & 0.0003 & 0.016 \\
\hline & $\mathrm{LF} 25 \mathrm{~min}$ & & & & & 0.0044 & 0.0004 & 0.0003 & 0.041 \\
\hline & LF $35 \mathrm{~min}$ & 0.046 & 0.018 & 0.18 & 0.0084 & 0.0040 & 0.0006 & 0.0003 & 0.062 \\
\hline & $\begin{array}{c}\text { After } \mathrm{Ca}-\mathrm{Fe} \\
\text { wire } \\
\text { injection }\end{array}$ & & & & & 0.0028 & 0.0029 & 0.0006 & 0.048 \\
\hline & $\begin{array}{c}\text { Soft blowing } \\
9 \mathrm{~min} \\
\text { after } \mathrm{Ca}\end{array}$ & 0.040 & 0.025 & 0.19 & 0.0084 & 0.0026 & 0.0033 & 0.0007 & 0.049 \\
\hline
\end{tabular}

Table 2. Steel composition at different steps (wt $\%$ ).

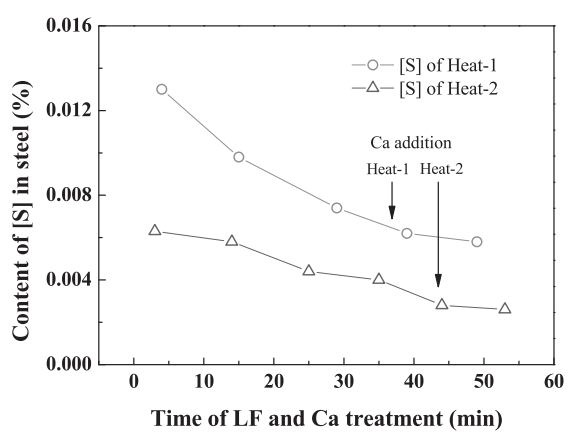

(a)

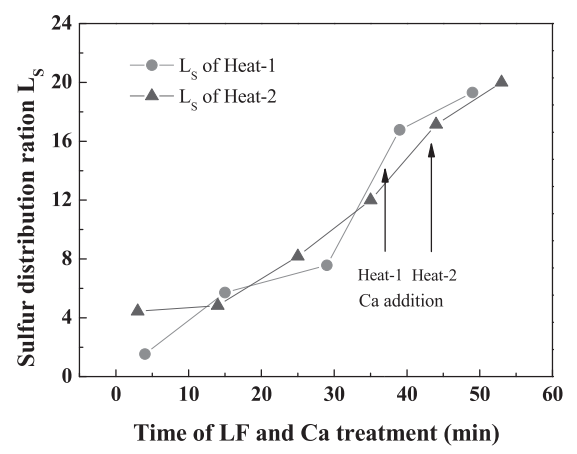

(b)

Fig. 1. Variation of (a)-[S] and (b)- $\mathrm{L}_{S}$ during the refining process. 


\subsection{Total Oxygen and Nitrogen in Steel}

Total oxygen in steel is well used to be a cleanliness criterion, especially for LCAK steel, and it really represents the level of small oxide inclusions (less than $50 \mu \mathrm{m}$ ) only. ${ }^{10-12)}$ The difference in nitrogen content between steelmaking vessels is an indicator of the air entrainment during transfer operations. ${ }^{12,13)}$

The variation of nitrogen and total oxygen in steel samples is shown in Fig. 2. Owing to the deoxidation and the removal of inclusions, the total oxygen decreased significantly during LF refining process, especially at the earlier stage. After Ca treatment, both the total oxygen and nitrogen increased more or less, which might be attributed to the reoxidation caused by the boiling of molten steel on the near-surface of the molten pool at time of $\mathrm{Ca}-\mathrm{Fe}$ wire injection that was induced by the high steam pressure of calcium. The nitrogen content during LF refining process was almost no apparent change but increased approximately 9 ppm after the addition of calcium alloy.

\subsection{Composition and Morphology of Inclusions}

Over 1000 inclusions larger than $1 \mu \mathrm{m}$ were analyzed for each steel sample using ASPEX by scanning over $60 \mathrm{~mm}^{2}$. The variation of the composition and morphology of inclusions during LF refining process is shown in Fig. 3, where the scanning area and the detected number of inclusions on each sample are presented, and the curved area in the ternary phase diagram is the liquid region of low melting inclusions at $1873 \mathrm{~K}$.

At 4 min refining time, inclusions were mainly alumina with irregular or cluster shape. At $15 \mathrm{~min}$, although the composition of inclusions had no obvious change, their morphology were relatively more regular. After 29 min refining, the $\mathrm{MgO}$ and $\mathrm{CaO}$ contents in inclusions increased (Fig. 3(c)). The $\mathrm{MgO}-\mathrm{Al}_{2} \mathrm{O}_{3}$ inclusions were mainly $>5 \mu \mathrm{m}$, while calcium aluminate inclusions were smaller, mainly $<$ $5 \mu \mathrm{m}$. Two possible reasons are: (1) For the current experimental conditions, alumina were changed to $\mathrm{MgO}-\mathrm{Al}_{2} \mathrm{O}_{3}$

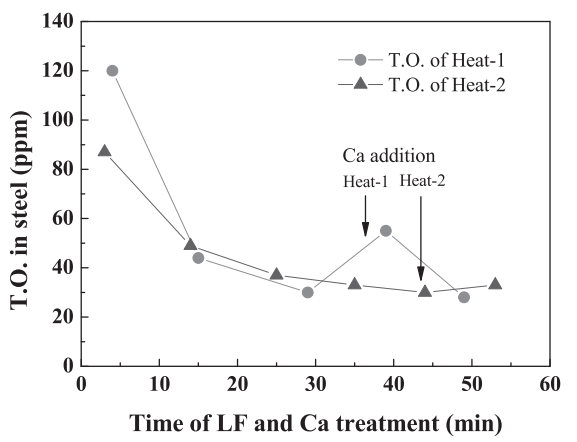

(a)

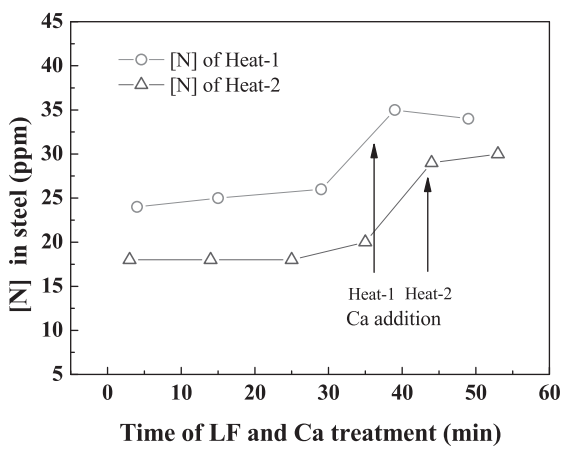

(b)

Fig. 2. Variation of (a) T.O. and (b) [N] during LF and Ca treatment.

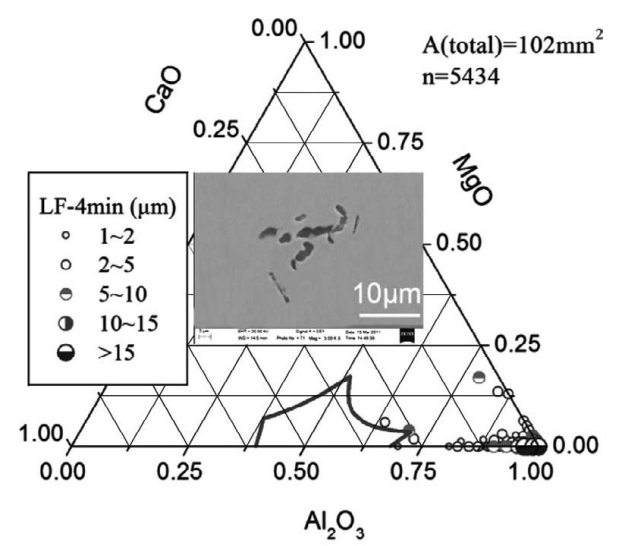

(a)

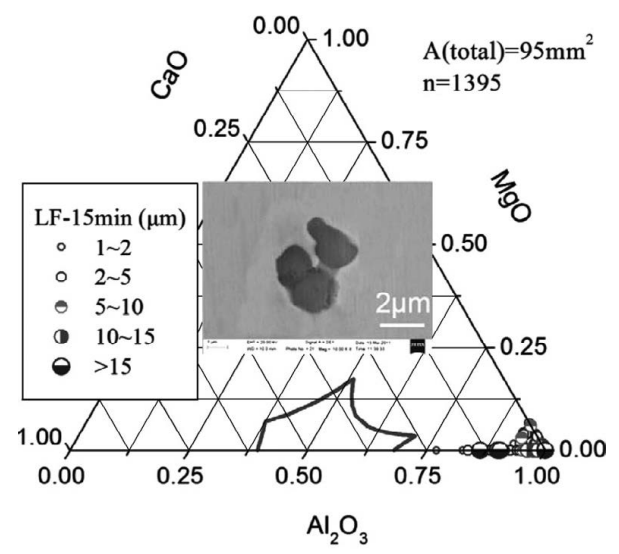

(b)

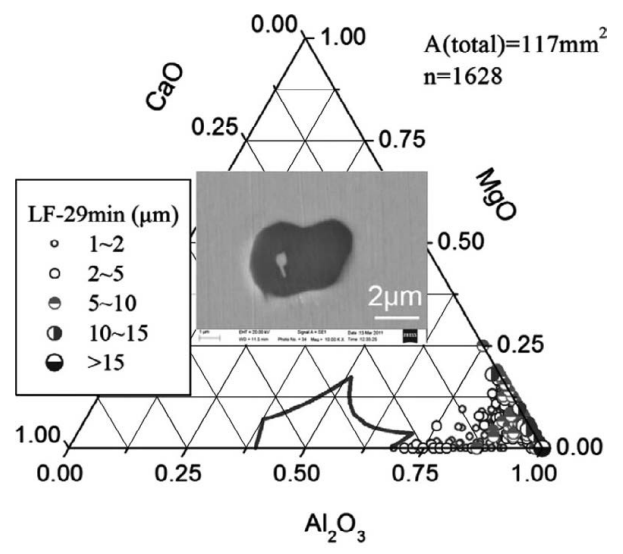

(c)

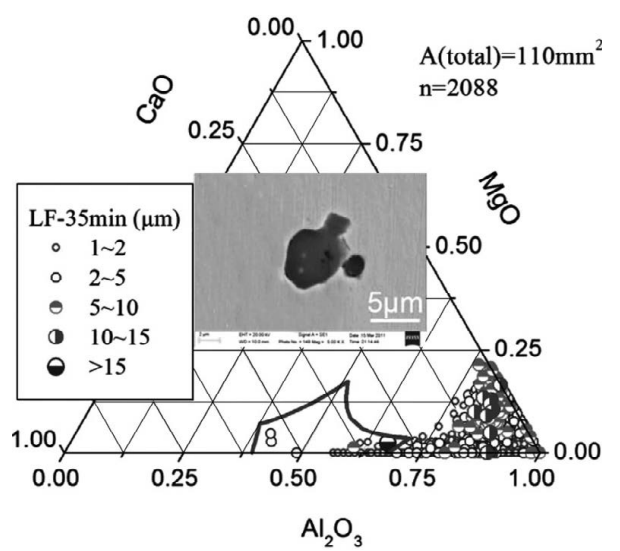

(d)

Fig. 3. Variation of inclusion composition and typical morphology during LF refining process, (a) LF-4 min; (b) LF-15 min; (c) LF-29 min; (d) LF-35 min. 
inclusions firstly, and then changed to calcium aluminates as the dissolved calcium content in steel increased. (2) As reported, ${ }^{14)} \mathrm{MgO}-\mathrm{Al}_{2} \mathrm{O}_{3}$ inclusions larger than $5 \mu \mathrm{m}$ are difficult to be modified while $<2 \mu \mathrm{m} \mathrm{MgO}-\mathrm{Al}_{2} \mathrm{O}_{3}$ inclusions are easy to be modified into calcium aluminates. Due to the low calcium concentration in steel and the slow diffusion speed of calcium ion in inclusions, the change of $\mathrm{MgO}-$ $\mathrm{Al}_{2} \mathrm{O}_{3}$ inclusions was slow, leaving the insufficient change of large size spinel inclusions and the existence of small calcium aluminate inclusions. As refining time further increasing, the contents of $\mathrm{MgO}$ and $\mathrm{CaO}$ in inclusions increased as well (Fig. 3(d)). However, the compositions of most inclusions, especially those $>5 \mu \mathrm{m}$ ones were still located out of the liquid zone at $1873 \mathrm{~K}$. Some inclusions at this time were changed to nearly spherical.

Liquid inclusions are desired to avoid nozzle clogging during casting. It is well known that calcium can modify alumina inclusions into calcium aluminates or react with sulfur to form $\mathrm{CaS} .{ }^{15)}$ Thus, two connected ternary diagrams of $\mathrm{Al}_{2} \mathrm{O}_{3}-\mathrm{MgO}-\mathrm{CaO}$ system and $\mathrm{Al}_{2} \mathrm{O}_{3}-\mathrm{CaS}-\mathrm{CaO}$ system are used to study the variation of inclusion composition after calcium treatment.

The composition of inclusions in steel at soft blowing time of $3 \mathrm{~min}$ and $13 \mathrm{~min}$ after calcium treatment of Heat1 are shown in Figs. 4 and 5, indicating that with time increasing more and more $\mathrm{MgO}-\mathrm{Al}_{2} \mathrm{O}_{3}-\mathrm{CaO}$ inclusions were shifted away from the corner of alumina and were modified to liquid. Almost all inclusions that were mainly smaller than $5 \mu \mathrm{m}$ contained large amount of $\mathrm{CaS}$. With time increasing, the $\mathrm{Al}_{2} \mathrm{O}_{3}$ content in inclusions decreased and $\mathrm{CaS}$ content increased (shown in Fig. 5), which might be owing to the continuous modification reaction of $\mathrm{Al}_{2} \mathrm{O}_{3}$ to calcium aluminate and the reaction between sulfur and calcium to form $\mathrm{CaS}$. The current result is different from that of Verma et al. ${ }^{16,17)}$ who claimed that immediately after calcium treatment $\mathrm{CaS}$ formed adhering to alumina or spinel, and longer after calcium treatment the CaS disappeared and spinels were fully or partially modified. After calcium treatment most of the inclusions were changed to spherical shape and with small size of $<5 \mu \mathrm{m}$. Even after 13 min soft

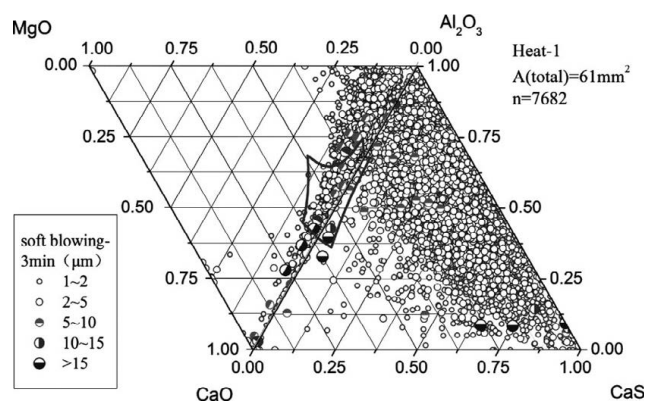

Fig. 4. Inclusion composition at $3 \mathrm{~min}$ after calcium treatment of Heat-1.

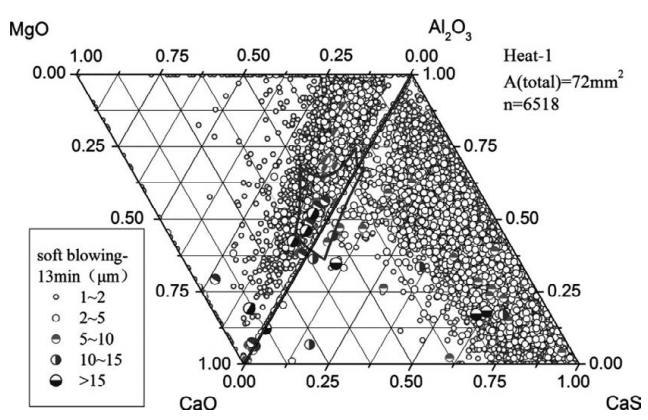

Fig. 5. Inclusion composition at $13 \mathrm{~min}$ after calcium treatment of Heat-1. blowing, many inclusions were still located out of the liquid zone on the $\mathrm{Al}_{2} \mathrm{O}_{3}-\mathrm{MgO}-\mathrm{CaO}$ ternary diagram.

Compared to Heat-1, inclusions after calcium treatment of Heat-2 contained more amount of $\mathrm{CaO}$ (Figs. 6 and 7), resulting in a better modification so that many inclusions changed to liquid at $1873 \mathrm{~K}$, especially the calcium aluminates with size $>5 \mu \mathrm{m}$, which formed by the direct reaction between the dissolved calcium and aluminum and oxygen. After 9 min soft blowing, the $\mathrm{CaO}$ content in inclusions increased compared to that immediately after $\mathrm{Ca}-\mathrm{Fe}$ wire injection, generating many large calcium aluminate inclusions with high melting point and a composition of $\mathrm{C}_{3} \mathrm{~A}+\mathrm{CaO}$ (where $\mathrm{C}$ is $\mathrm{CaO}$ and $\mathrm{A}$ is $\mathrm{Al}_{2} \mathrm{O}_{3}$ ) that were caused by slightly excessive calcium addition. Meanwhile, the morphology of inclusions changed to spheres and a great amount of $\mathrm{CaS}$ precipitated, the same as Heat-1. However, the number of $>5 \mu \mathrm{m}$ inclusions detected by ASPEX was larger than that of Heat-1. Compared Figs. 6 and 7, with time increasing after calcium addition for Heat-2, the number of large inclusions, especially $5-10 \mu \mathrm{m}$ ones, increased.

The element mappings of typical oxide inclusions during LF refining and calcium treatment are shown in Fig. 8, where inclusions (a) and (b) are from middle and later stages of LF refining respectively, and inclusions (c) and (d) are from earlier and later stages of soft blowing process after calcium treatment. At the middle stage of LF refining, spinel type inclusions with homogeneous elements distribution were formed firstly, as the refining time increased, $\mathrm{CaO}$ started to generate at the outside of the spinel inclusions. After calcium treatment, the inclusions changed to calcium aluminates or calcium magnesium aluminates. It should be noticed that the size of inclusions with uniform $\mathrm{Al}-\mathrm{Mg}-\mathrm{Ca}$ or $\mathrm{Al}-\mathrm{Ca}$ distribution were $<5 \mu \mathrm{m}$.

The average composition evolution of inclusions during LF refining and calcium treatment are presented in Figs. 9 and 10. The process of change of oxide inclusions was: alumina $\rightarrow$ spinel type $\rightarrow$ calcium aluminate. For Heat-1, after calcium treatment, the average composition of oxide inclusions was still out of the liquid zone, while that of Heat-2

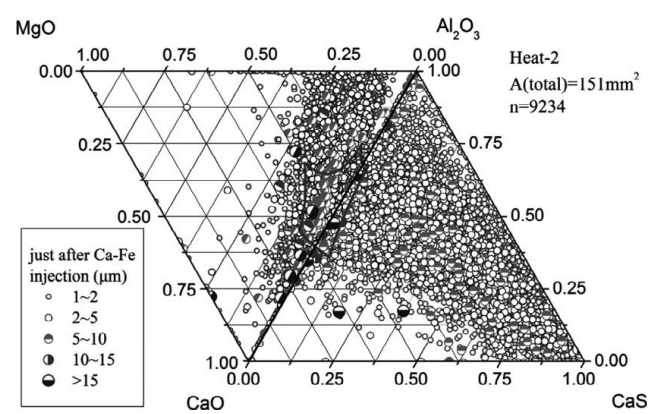

Fig. 6. Inclusion composition just after $\mathrm{Ca}-\mathrm{Fe}$ wire injection of Heat-2.

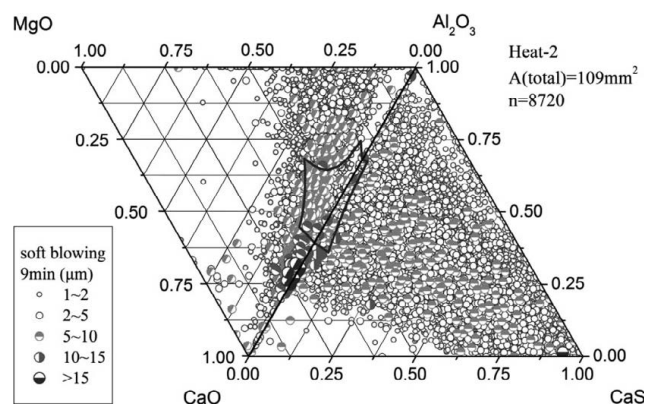

Fig. 7. Inclusion composition at 9 min after calcium treatment of Heat-2. 

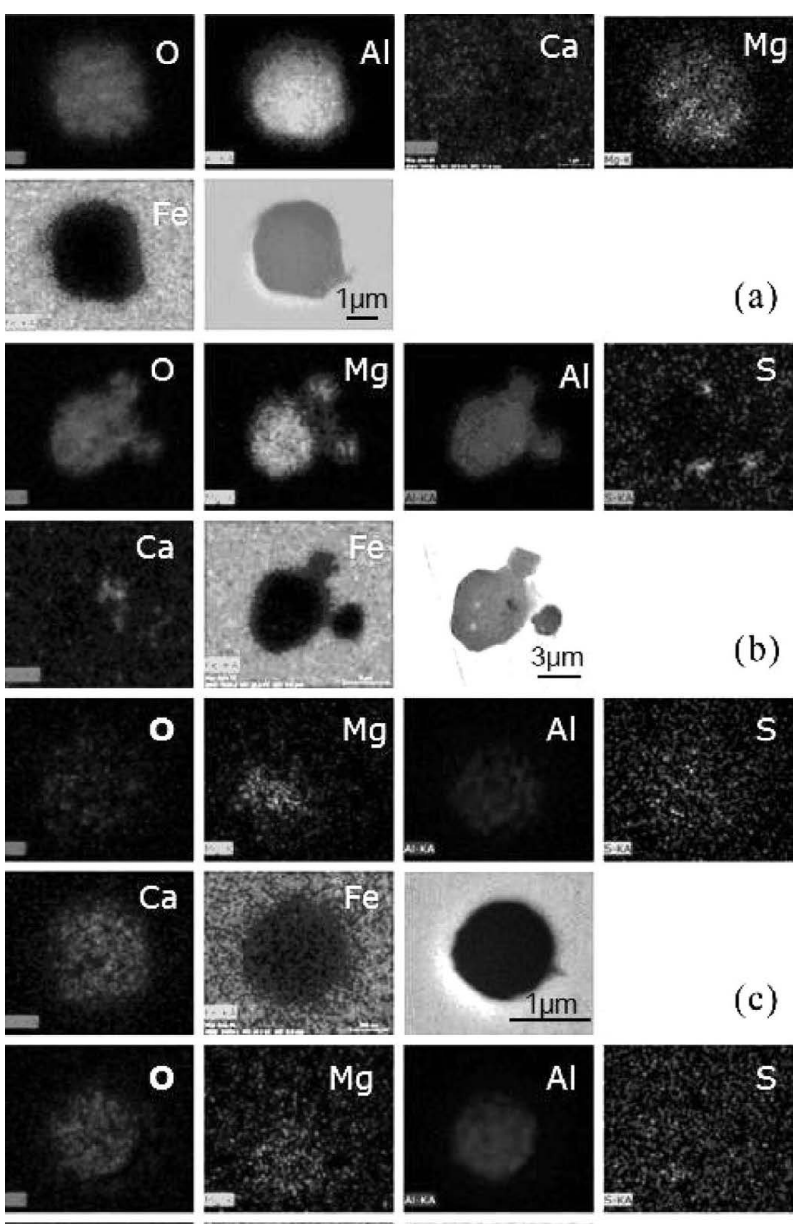

$\mathrm{Ca}$
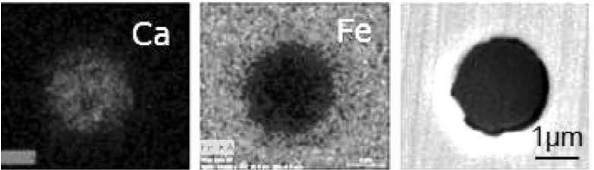

(d)

Fig. 8. Element mappings of typical oxide inclusions (a) spinel type with $\mathrm{Mg}$ and $\mathrm{Al}$ homogeneously distributed at middle stage of $\mathrm{LF}$; (b) $\mathrm{CaO}$ at outside before $\mathrm{Ca}$ treatment; (c) calciumaluminate with a small amount of $\mathrm{MgO}$ after $\mathrm{Ca}$ treatment; (d) calcium-aluminate or calcium-magnesium-aluminate with elements uniformly distributed after $\mathrm{Ca}$ treatment.

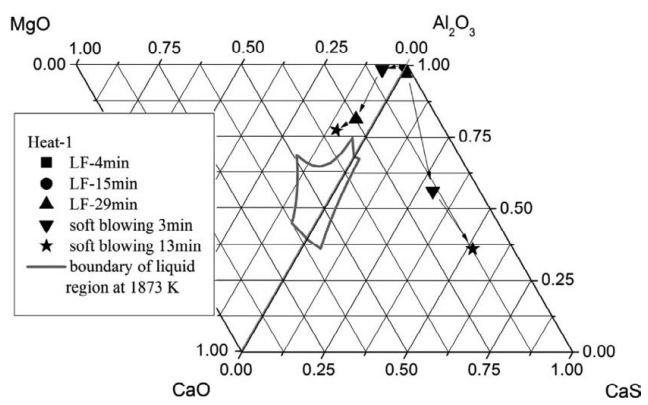

Fig. 9. Average composition evolution of inclusions during refining of Heat-1.

was changed to the expected liquid area. The main reason for this difference is that the precipitation of $\mathrm{CaS}$ consumed large amount of calcium that was expected to be used to modify inclusions to calcium aluminates with low melting point. Figure 9 clearly shows that with the increasing of soft blowing time in Heat-1, the average CaS content in inclusions increased while the $\mathrm{CaO}$ content changed little. However, for Heat-2, with time increasing after calcium addition,

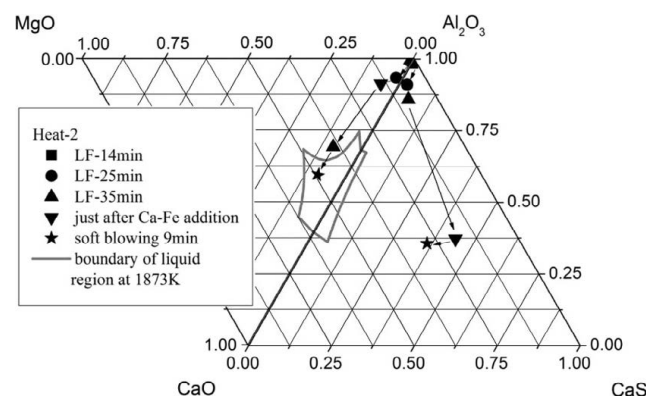

Fig. 10. Average composition evolution of inclusions during refining of Heat-2.
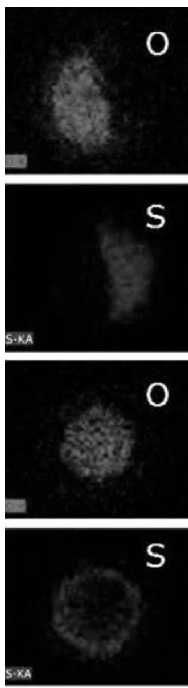

S
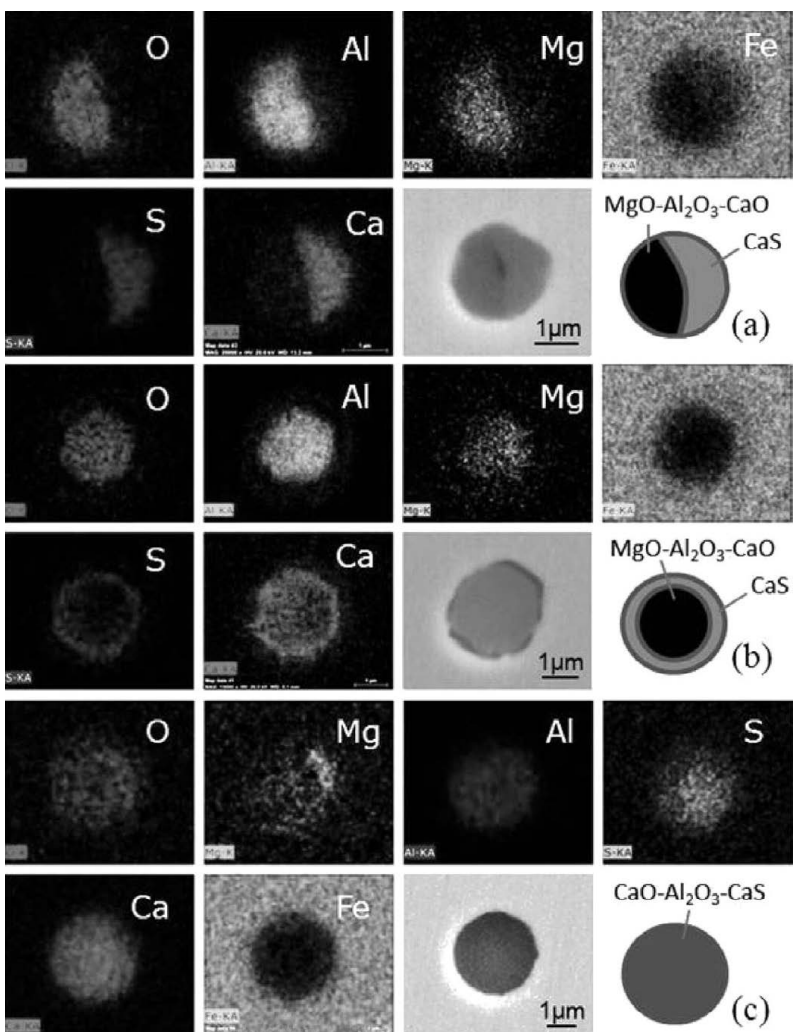

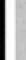

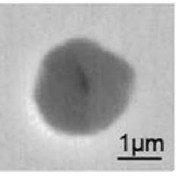

$\mathrm{MgO}-\mathrm{Al}_{2} \mathrm{O}_{3}-\mathrm{CaO}$

$\underline{1 \mu \mathrm{m}}$
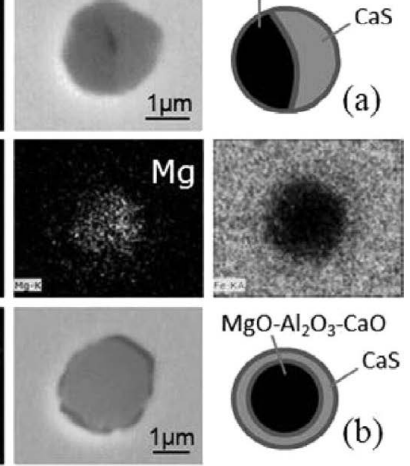

$\mathrm{MgO}-\mathrm{Al}_{2} \mathrm{O}_{3}-\mathrm{CaO}$
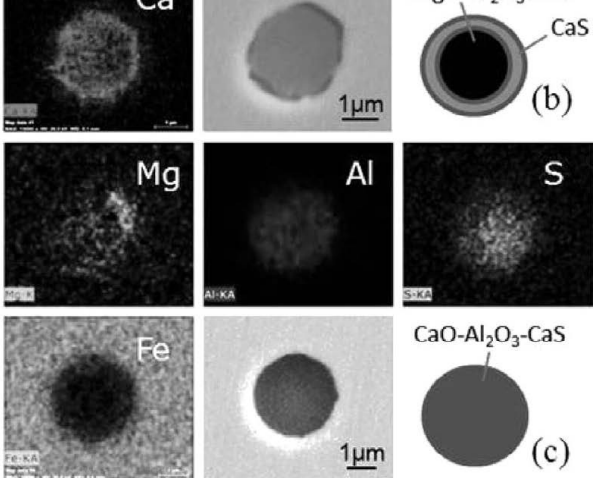

$\mathrm{CaO}-\mathrm{Al}_{2} \mathrm{O}_{3}$-CaS

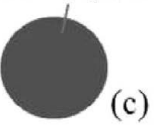

Fig. 11. The types of $\mathrm{CaS}$ distribution in inclusions, (a) collision with oxide; (b) surrounding oxide; (c) uniformly distributed within oxide.

the $\mathrm{CaO}$ content increased and $\mathrm{CaS}$ content decreased with almost constant $\mathrm{Al}_{2} \mathrm{O}_{3}$ content.

The distribution of $\mathrm{CaS}$ in inclusions after calcium treatment can be classified into three types: collision with oxide, surrounding oxide, and uniformly distributed within oxide, as shown in Fig. 11. For the first type, CaS occupied a part, even approximately half of a inclusion with a clear boundary line, like a $\mathrm{CaS}$ colliding with a spinel or calcium aluminate (Fig. 11(a)). For the second type, CaS surrounded a calcium magnesium aluminate, like a $\mathrm{CaS}$ ring precipitating the outside of an aluminate (Fig. 11(b)). For the third type, $\mathrm{CaS}$ homogeneously distributes within a calcium aluminate inclusion, and no obvious dividing boundary (Fig. 11(c)). The formation mechanisms of the three forms will be discussed later.

\subsection{Amount and Size Distribution of Inclusions}

The variation of ND and AF of inclusions during LF refining and calcium treatment is shown in Fig. 12. During the first $15 \mathrm{~min}$, both ND and AF decreased significantly. After 15 min refining, the ND of inclusions changed little, 


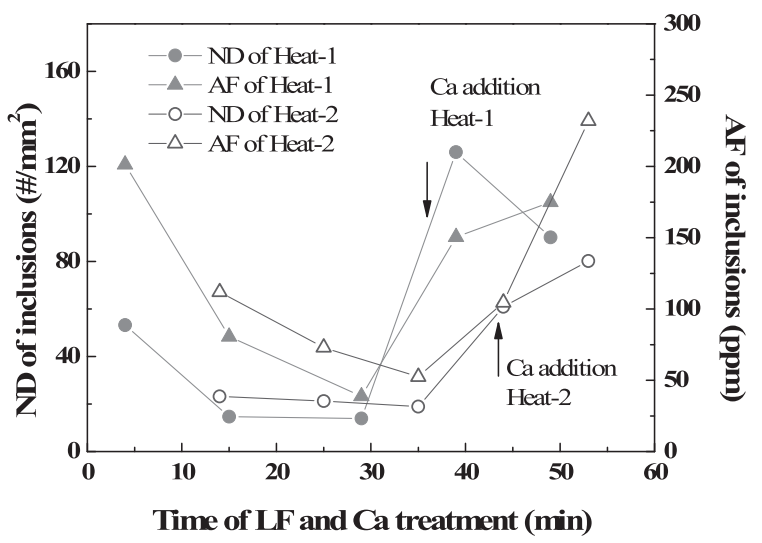

Fig. 12. Variation of ND and AF of inclusions during LF refining and calcium treatment.

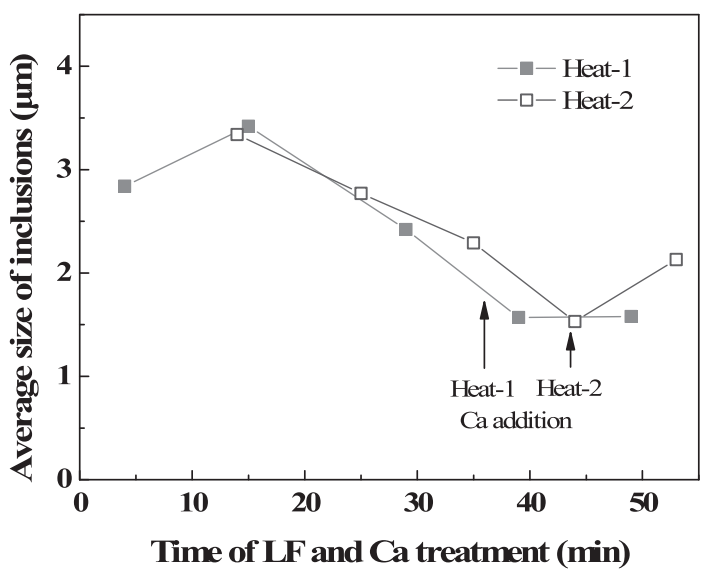

Fig. 13. Variation of the average size of inclusions during LF refining and calcium treatment.

while the AF continued to decrease before calcium treatment, which was consistent with the variation tendency of T.O. (Fig. 2). Since the AF of inclusions contains the factors of both ND and size, it is more accurate to characterize the content of inclusions. After calcium treatment, both of the two parameters increased sharply, which was caused by the massive generation of $\mathrm{CaS}$ inclusions and possible slight reoxidation of molten steel during the process of calcium addition.

The variation of the average size of inclusions is shown in Fig. 13. With the rapid decreasing of the ND of inclusions at the first $15 \mathrm{~min}$, the average size of inclusions increased, which was caused by the aggregation of inclusions. Afterwards, the average size kept decreasing until the addition of calcium due to the fact that large inclusions were removed by flow transport and bubble floatation, which explains the decreasing of AF but not ND. After calcium treatment, the average size of inclusions increased again, especially for Heat-2 owing to the independent growth of inclusions by element diffusion or the aggregation of inclusions.

\section{Discussions}

The main task of LF refining and calcium treatment is to modify inclusions from solid to liquid at steelmaking temperature to prevent nozzle clogging during continuous casting. As mentioned above, the composition of inclusions changed obviously during the refining and calcium treatment process. However, even after calcium treatment, many oxide inclusions especially during Heat-1 were still not modified to liquid ones because of the precipitation of large

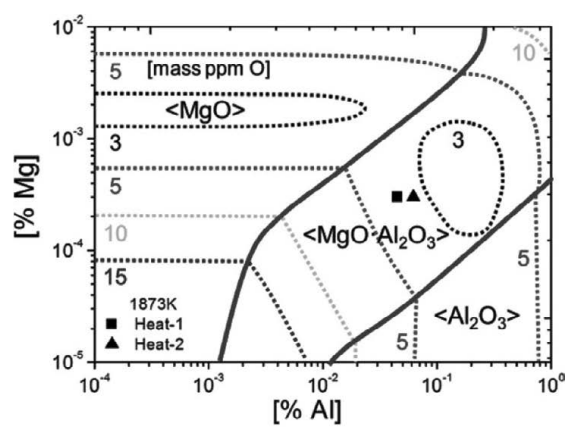

(a)

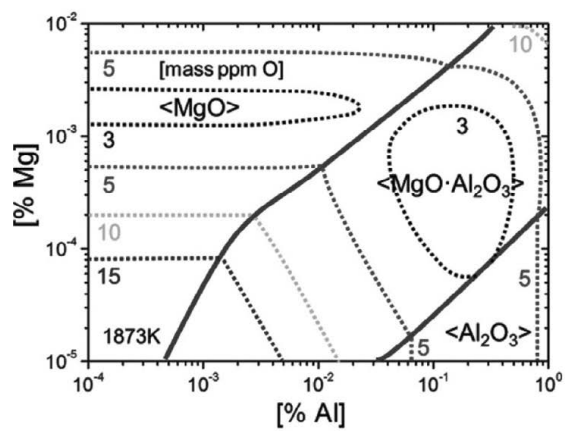

(b)

Fig. 14. Phase stability diagram of $\mathrm{MgO}, \mathrm{MgO} \cdot \mathrm{Al}_{2} \mathrm{O}_{3}$ and $\mathrm{Al}_{2} \mathrm{O}_{3}$ inclusions, and iso-oxygen contour lines at $1873 \mathrm{~K}$ with the experimental data, where $[\% \mathrm{Ca}]=0$, (a) $a_{\mathrm{Mg} \cdot \mathrm{Al}_{2} \mathrm{O}_{3}}=1$;

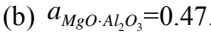

amount of $\mathrm{CaS}$ inclusions. In order to understand the modification of inclusions by calcium treatment more accurately, the thermodynamic calculation was performed and discussed below.

\subsection{Formation Thermodynamics of Oxide Inclusions}

4.1.1. Formation of $\mathrm{Al}_{2} \mathrm{O}_{3}, \mathrm{MgO}$ and $\mathrm{MgO} \cdot \mathrm{Al}_{2} \mathrm{O}_{3}$ Inclusions

To study the possibility of the formation of spinel inclusions, the $\mathrm{MgO} / \mathrm{MgO} \cdot \mathrm{Al}_{2} \mathrm{O}_{3} / \mathrm{Al}_{2} \mathrm{O}_{3}$ stability phase diagram is assessed by performing thermodynamic calculations for the formation of $\mathrm{MgO}, \mathrm{MgO} \cdot \mathrm{Al}_{2} \mathrm{O}_{3}$ and $\mathrm{Al}_{2} \mathrm{O}_{3}$ inclusion in molten steel. The calculation procedure and the thermodynamic data were described elsewhere. ${ }^{14)}$

In order to compare the effect of activity of $\mathrm{MgO} \cdot \mathrm{Al}_{2} \mathrm{O}_{3}$ on the formation region of $\mathrm{MgO} \cdot \mathrm{Al}_{2} \mathrm{O}_{3}$, The phase stability diagrams as a function of $[\mathrm{Mg}]$ and $[\mathrm{Al}]$ contents in steel at $1873 \mathrm{~K}$ are calculated for two cases (case 1: $a_{\mathrm{MgO} O}=1, a_{\mathrm{Al}_{2} \mathrm{O}_{3}}=$ 1, $a_{\mathrm{MgO} \cdot \mathrm{Al}_{2} \mathrm{O}_{3}}=1$; case 2: $a_{\mathrm{MgO}}=1, a_{\mathrm{Al}_{2} \mathrm{O}_{3}}=1, a_{\left.{\mathrm{MgO} \cdot \mathrm{Al}_{2} \mathrm{O}_{3}}=0.47\right)}$ and are shown in Fig. 14, which agree well with that by Itoh. ${ }^{18)}$ It is indicated that with lower activity of $\mathrm{MgO} \cdot \mathrm{Al}_{2} \mathrm{O}_{3}$, the $\mathrm{MgO} \cdot \mathrm{Al}_{2} \mathrm{O}_{3}$ stable region becomes wider, which means its formation is easier. Besides, the low oxygen activity zone in $\mathrm{MgO} \cdot \mathrm{Al}_{2} \mathrm{O}_{3}$ stable region becomes wider as well, which indicates that the formation of $\mathrm{MgO} \cdot \mathrm{Al}_{2} \mathrm{O}_{3}$ can help to obtain lower oxygen activity easier. The formation of $\mathrm{MgO} \cdot \mathrm{Al}_{2} \mathrm{O}_{3}$ is also affected by the dissolved oxygen in steel. This figure shows that thermodynamically when $[\% \mathrm{Al}]=$ $0.02 \sim 0.05$ (the general aluminum content in LCAK steel), $\mathrm{MgO} \cdot \mathrm{Al}_{2} \mathrm{O}_{3}$ can be formed when the $[\mathrm{Mg}]$ in steel ranges from $0.3 \mathrm{ppm}$ to $7 \mathrm{ppm}$ in case of $a_{\mathrm{MgO} \cdot \mathrm{Al}_{2} \mathrm{O}_{3}}=1$ and from $0.2 \mathrm{ppm}$ to $9 \mathrm{ppm}$ in case of $a_{\mathrm{MgOAl}_{2} \mathrm{O}_{3}}=0.47$. The steel composition before calcium treatment located in the $\mathrm{MgO} \cdot \mathrm{Al}_{2} \mathrm{O}_{3}$ stable region (shown as the symbols in Fig. 14(a)), however, actually the alumina was not fully changed to $\mathrm{MgO} \cdot \mathrm{Al}_{2} \mathrm{O}_{3}$ spinel in the plant experiment. 


\subsubsection{Formation of Calcium Aluminate}

Many studies on the modification of alumina by calcium treatment have been reported, ${ }^{19-27)}$ and some models have been proposed. ${ }^{25-27)}$ There are few thermodynamic calculation on the transformation of $\mathrm{MgO} \cdot \mathrm{Al}_{2} \mathrm{O}_{3}$ spinel inclusions by calcium treatment. ${ }^{14,16,17)}$

Composite deoxidation by $\mathrm{Mg}, \mathrm{Al}$ and $\mathrm{Ca}$ is considered. If the $\mathrm{CaO}-\mathrm{MgO}-\mathrm{Al}_{2} \mathrm{O}_{3}$ inclusions are liquid in molten steel, they have been proved to be the most stable phase. ${ }^{28)}$ Neglecting the small amount of $\mathrm{MgO}$, the composition of the calcium aluminate inclusions should be close to $12 \mathrm{CaO} \cdot 7 \mathrm{Al}_{2} \mathrm{O}_{3}$. The formation of $12 \mathrm{CaO} \cdot 7 \mathrm{Al}_{2} \mathrm{O}_{3}$ can be expressed by the following equation.

$$
12 \mathrm{CaO} \cdot 7 \mathrm{Al}_{2} \mathrm{O}_{3}=14[\mathrm{Al}]+12[\mathrm{Ca}]+33[\mathrm{O}]
$$

From the related thermodynamic data of deoxidation equilibrium of aluminum and calcium reported by Itoh et $a .^{29,30)}$ and the Eqs. (4)-(5) below, the equilibrium constant of Eq. (3) can be derived as Eq. (6).

$$
\begin{aligned}
& \left(12 \mathrm{CaO} \cdot 7 \mathrm{Al}_{2} \mathrm{O}_{3}\right)=12(\mathrm{CaO})+7\left(\mathrm{Al}_{2} \mathrm{O}_{3}\right) \\
& \log K_{1}=-31.97+32280 / \mathrm{T}^{31)} \\
& \log K_{2}=9.866-371460 / T
\end{aligned}
$$

The solid phase of calcium aluminate at steelmaking temperature is assumed as $\mathrm{CaO} \cdot 2 \mathrm{Al}_{2} \mathrm{O}_{3}$, and the formation can be expressed by Eq. (7), the equilibrium constant of which, shown as Eq. (8), is derived from those of aluminum and calcium deoxidation reported by Itoh et al. ${ }^{29,30)}$ and of the formation of $\mathrm{CaO} \cdot 2 \mathrm{Al}_{2} \mathrm{O}_{3}$ from $\mathrm{CaO}$ and $\mathrm{Al}_{2} \mathrm{O}_{3}$ reported by Nagata et $a l .{ }^{32)}$

$$
\begin{gathered}
\mathrm{CaO} \cdot 2 \mathrm{Al}_{2} \mathrm{O}_{3}=[\mathrm{Ca}]+4[\mathrm{Al}]+7[\mathrm{O}] . \\
\log K_{3}=21.297-97003 / T \ldots \ldots .
\end{gathered}
$$

The activity of dissolved element $\mathrm{i}$ in molten steel is based on $1 \%$ mass fraction of Henry's standard state. The first and second order interaction coefficients used in the current work were listed elsewhere. ${ }^{18,29,33-35)}$ Since some of the second order interaction coefficients of $\mathrm{Ca}$ are invalid, the relevant second order interaction coefficients of $\mathrm{Ca}$ are not considered in this study. The activity of $12 \mathrm{CaO} \cdot 7 \mathrm{Al}_{2} \mathrm{O}_{3}$ and $\mathrm{CaO} \cdot 2 \mathrm{Al}_{2} \mathrm{O}_{3}$, whose standard state are taken as pure solid, are approximately taken as unity. The steel composition used in the calculation is the average values of the two heats after calcium treatment shown in Table 2 .

The calculated stable phase diagrams of $\mathrm{MgO}$, $\mathrm{MgO} \cdot \mathrm{Al}_{2} \mathrm{O}_{3}, \mathrm{CA}_{2}$ and $\mathrm{C}_{12} \mathrm{~A}_{7}$ in cases of $[\mathrm{Ca}]=1 \mathrm{ppm}$ and $[\mathrm{Ca}]=2$ ppm are shown in Fig. 15. Under the current contents of $\mathrm{Al}$ and $\mathrm{Mg}$, the full modification of spinel to liquid calcium aluminate could thermodynamically occur even if only $2 \mathrm{ppm}$ of dissolved calcium exists in the steel.

However, in the current work the formation of MA or CMA (C: $\mathrm{CaO}, \mathrm{M}: \mathrm{MgO}, \mathrm{A}: \mathrm{Al}_{2} \mathrm{O}_{3}$ ) is due to the modification of other inclusions, for example, MA is formed by the reaction between $[\mathrm{Mg}]$ and $\mathrm{Al}_{2} \mathrm{O}_{3}$, and $\mathrm{CMA}$ is formed by the reaction between [Ca] and $\mathrm{MA}$. The formation of MA and CMA involves the diffusion of elements both in liquid steel and in solid oxide. Since the diffusion in solid oxide is much slower than in liquid steel and liquid oxide, the formation rate of MA and CMA mainly depends on the diffusion in solid oxide, which is much slow. Thus, it is assumed that the formation of MA and CMA from full modification of other inclusions is under non-equilibrium in the plant production especially when the oxide is large and before $\mathrm{Ca}$ treatment. That is why although there existed $3-8 \mathrm{ppm} \mathrm{Ca}$ before calcium treatment, solid inclusions with high amount of $\mathrm{Al}_{2} \mathrm{O}_{3}$ rather than liquid calcium aluminates were observed in the current study. More $\mathrm{Ca}$ is required and the operation of $\mathrm{Ca}$ treatment promotes the reaction.

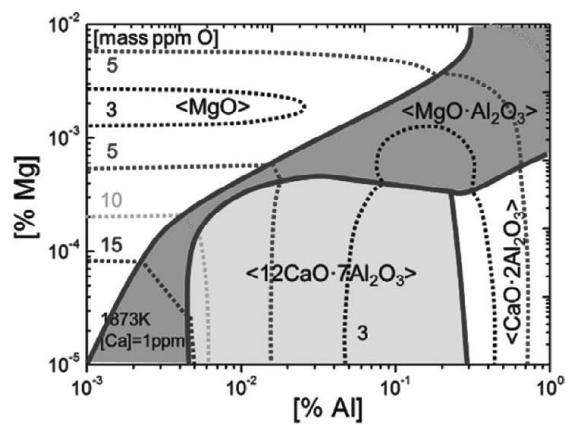

(a)

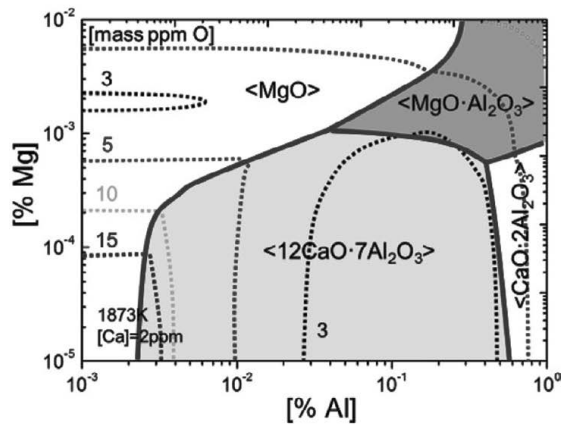

(b)

Fig. 15. Stability diagram of $\mathrm{MgO}, \mathrm{MgO} \cdot \mathrm{Al}_{2} \mathrm{O}_{3}, 12 \mathrm{CaO} \cdot 7 \mathrm{Al}_{2} \mathrm{O}_{3}$ and $\mathrm{CaO} \cdot 2 \mathrm{Al}_{2} \mathrm{O}_{3}$, and iso-oxygen contour lines at $1873 \mathrm{~K}$, (a) $[\mathrm{Ca}]=1 \mathrm{ppm}$, (b) $[\mathrm{Ca}]=2 \mathrm{ppm}$.

\subsection{Formation Thermodynamics of Calcium Sulfide}

$\mathrm{CaS}$ inclusions may be generated directly by the reaction between sulfur and calcium, shown as Eq. (9), the collision between oxide and sulfide, as observed in the current experiment, may be by this approach (Fig. 11). CaS inclusions may also be generated by the reaction between $\mathrm{CaO}$ and sulfur (Eq. (11)), and the surrounding type and uniform type in Fig. 11 may belong to this case.

$$
\begin{array}{r}
{[\mathrm{Ca}]+[\mathrm{S}]=(\mathrm{CaS}) \ldots \ldots \ldots \ldots \ldots \ldots \ldots \ldots} \\
\Delta G_{1}^{\theta}=-530900+116.2 T(\mathrm{~J} / \mathrm{mol})^{36)}
\end{array}
$$$$
3(\mathrm{CaO})_{\text {in inclusion }}+3[\mathrm{~S}]+2[\mathrm{Al}]=3(\mathrm{CaS})+\left(\mathrm{Al}_{2} \mathrm{O}_{3}\right)_{\text {in inclusion }}
$$$$
\Delta G_{2}^{\theta}=-879760+298.73 T(\mathrm{~J} / \mathrm{mol})^{25)} .
$$

During the calculation, the activity of $\mathrm{CaS}$, whose standard state is taken as pure solid, is assumed to be unity. And the activities of elements $\mathrm{Ca}$ and $\mathrm{S}$ are based on $1 \%$ mass fraction of Henry's standard state. The steel composition after $\mathrm{Ca}$ treatment shown in Table 2 and the aforementioned first order interaction coefficients ${ }^{18,29,34,35)}$ are also used in the calculation.

At steelmaking temperature, the precipitation of $\mathrm{CaS}$ decreases the modification effect of alumina by calcium treatment as it hinders the formation of calcium aluminate, and causes nozzle clogging additionally. Furthermore, the formation of $\mathrm{CaS}$ at casting temperature worsens the castability of steel. Therefore, the control of steel composition is discussed at $1873 \mathrm{~K}$ (steelmaking temperature) and $1823 \mathrm{~K}$ (casting temperature).

The calculated stability diagram of $\mathrm{CaS}$ in the case of direct formation at $1873 \mathrm{~K}$ and $1823 \mathrm{~K}$ is shown in Fig. 16, indicating that at equilibrium, when the sulfur content in steel is $0.0040 \%$, the calcium content should be less than $0.0048 \%$ in order to prevent the direct formation of $\mathrm{CaS}$ at $1873 \mathrm{~K}$, while at $1823 \mathrm{~K}$ it should be less than $0.0019 \%$.

The two symbols present the steel composition after cal- 


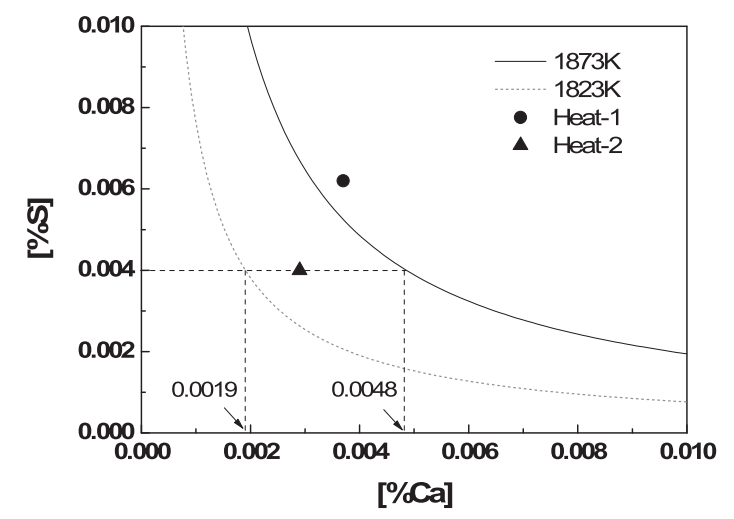

Fig. 16. Stability diagram of $\mathrm{CaS}$ in case of direct precipitation.

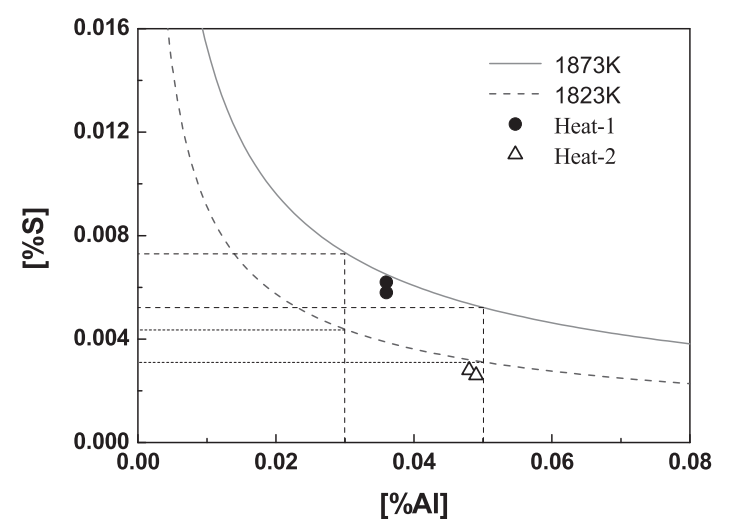

Fig. 17. Stability diagram of $\mathrm{CaS}$ by reacting with $\mathrm{CaO}$ in $\mathrm{C}_{12} \mathrm{~A}_{7}$ inclusions.

cium treatment, showing that at $1873 \mathrm{~K}$, CaS may be formed directly in Heat-1, while the direct $\mathrm{CaS}$ formation can be avoided in Heat-2, however, it may be formed as the temperature decreases. Besides, because of the fixed location of $\mathrm{Ca}-\mathrm{Fe}$ wire injection, the calcium content may be very high at local areas, inducing the direct formation of $\mathrm{CaS}$.

For case two that sulfur reacts with $\mathrm{CaO}$, owing to the low solubility of $\mathrm{CaS}$ in calcium aluminate, about 3.3 mass $\%$ at $\mathrm{CaO} / \mathrm{Al}_{2} \mathrm{O}_{3}=1.0$ and at $1873 \mathrm{~K}$ reported by Ozturk, ${ }^{37)}$ the activity of $\mathrm{CaS}$ is assumed to be equal to 1 . It is assumed that the calcium aluminate is $\mathrm{C}_{12} \mathrm{~A}_{7}$. Ye et al. ${ }^{25)}$ calculated the activities of $\mathrm{CaO}$ and $\mathrm{Al}_{2} \mathrm{O}_{3}$ to be 0.526 and 0.0267 respectively. The relationships between [Al] and [S] at equilibrium with liquid $\mathrm{C}_{12} \mathrm{~A}_{7}$ and $\mathrm{CaS}$ inclusions at $1873 \mathrm{~K}$ and $1823 \mathrm{~K}$ are shown in Fig. 17.

As shown in Fig. 17, the [S] content for CaS precipitation decreased with increasing [Al] content in steel. The temperature influences the precipitation significantly. Lower temperature favors the precipitation of CaS. Thus, the calcium treatment temperature could be increased in order to prevent the formation of $\mathrm{CaS}$. Thermodynamically, if the [Al] content in steel is $0.03 \%-0.05 \%$, in order to prevent the precipitation of $\mathrm{CaS}$ on surface of liquid calcium aluminate, the [S] content should be controlled less than $0.0073 \%$ $0.0052 \%$ at $1873 \mathrm{~K}$ and less than $0.0044 \%-0.0031 \%$ at $1823 \mathrm{~K}$.

$\mathrm{CaS}$ is a simple compound, and there is no composition change in its formation. In addition, $\mathrm{CaS}$ usually forms on the surface of inclusions where the component has been changed to liquid $\mathrm{C}_{12} \mathrm{~A}_{7}$, such as the aforementioned surrounding type, the formation rate mainly depends on the diffusion of elements such as [S] and [Ca] in liquid steel and ions in liquid oxide, which is much faster than in solid oxide, so it is assumed that the formation of $\mathrm{CaS}$ is under equilibrium. The symbols shown in the figure represent the steel composition after calcium treatment of the two experimental heats. In Heat-1 the CaS precipitation on surface of calcium aluminate could be avoided if the temperature is over $1873 \mathrm{~K}$, while in Heat-2 CaS would hardly precipitate by reacting with $\mathrm{CaO}$ in inclusions even though at $1823 \mathrm{~K}$. Thus, it is harder for CaS precipitation in Heat-2 than in Heat-1, which is consistent with the experimental observation.

It is certain that the solidification of steel promotes the precipitation of $\mathrm{CaS}$ because of the segregation of elements during cooling and solidification process. Thus, CaS probably precipitates on the surface or in the inner part of $\mathrm{MgO} \cdot \mathrm{Al}_{2} \mathrm{O}_{3}$ spinel or calcium aluminate inclusions even though there is little $\mathrm{CaS}$ at steelmaking temperature, leading to the existence of $\mathrm{CaS}$ distribution type of surrounding oxide or uniformly distributed within oxide.

\subsection{Change Mechanism of Inclusions}

According to the experimental results (Figs. 8 and 11), a change mechanism for both oxide and sulfide inclusions is proposed.

The $[\mathrm{Mg}]$ and $[\mathrm{Ca}]$ created by the reaction between $[\mathrm{Al}]$ in molten steel and $\mathrm{MgO}$ and $\mathrm{CaO}$ in slag or refractory ${ }^{20,38)}$ enter the bulk of melt, and transfer to the surface of $\mathrm{Al}_{2} \mathrm{O}_{3}$ inclusions. Then some $\mathrm{MgO} \cdot \mathrm{Al}_{2} \mathrm{O}_{3}$ and $\mathrm{CaO}-\mathrm{MgO}-\mathrm{Al}_{2} \mathrm{O}_{3}$ form on the surface of $\mathrm{Al}_{2} \mathrm{O}_{3}$ inclusions as Eqs. (13) and (14) respectively:

$$
\begin{aligned}
3[\mathrm{Mg}]+4\left(\mathrm{Al}_{2} \mathrm{O}_{3}\right) & =3\left(\mathrm{MgO} \cdot \mathrm{Al}_{2} \mathrm{O}_{3}\right)+2[\mathrm{Al}] \ldots . .(13) \\
\mathrm{x}[\mathrm{Ca}]+(\mathrm{y}+\mathrm{x} / 3)\left(\mathrm{Al}_{2} \mathrm{O}_{3}\right) & =\mathrm{x}(\mathrm{CaO}) \cdot \mathrm{y}\left(\mathrm{Al}_{2} \mathrm{O}_{3}\right)+2 \mathrm{x} / 3[\mathrm{Al}]
\end{aligned}
$$

Since the diffusion of $\mathrm{Mg}$ is faster than $\mathrm{Ca}$ in a same matrix, ${ }^{39-41)}$ MA generates earlier than CMA.

The modification mechanism of large spinel inclusions by calcium treatment is illustrated in Fig. 18, which gives the unreacted core model of change of $\mathrm{MgO}-\mathrm{Al}_{2} \mathrm{O}_{3}$ system inclusion into $\mathrm{CaO}-\mathrm{Al}_{2} \mathrm{O}_{3}$ system inclusion. Firstly, $\mathrm{MgO} \cdot \mathrm{Al}_{2} \mathrm{O}_{3}$ inclusion reacts with $[\mathrm{Ca}]$ on its surface, expressed by Eq. (15):

$\mathrm{x}[\mathrm{Ca}]+\left(\mathrm{yMgO} \cdot \mathrm{zAl}_{2} \mathrm{O}_{3}\right)=\left(\mathrm{xCaO} \cdot(\mathrm{y}-\mathrm{x}) \mathrm{MgO} \cdot \mathrm{zAl}_{2} \mathrm{O}_{3}\right)+\mathrm{x}[\mathrm{Mg}]$

A CaO $\cdot \mathrm{MgO} \cdot \mathrm{Al}_{2} \mathrm{O}_{3}$ layer generates on the surface of the $\mathrm{MgO} \cdot \mathrm{Al}_{2} \mathrm{O}_{3}$ inclusion. The [Ca] in the molten steel transfers to the surface of $\mathrm{CaO} \cdot \mathrm{MgO} \cdot \mathrm{Al}_{2} \mathrm{O}_{3}$ layer while the $[\mathrm{Mg}]$ created by the reaction transfers from the surface into the molten steel. The following reaction takes place on the outer surface of the $\mathrm{CaO} \cdot \mathrm{MgO} \cdot \mathrm{Al}_{2} \mathrm{O}_{3}$ layer:

$[\mathrm{Ca}]+\left(\mathrm{xCaO} \cdot \mathrm{yMgO} \cdot \mathrm{zAl}_{2} \mathrm{O}_{3}\right)=((\mathrm{x}+1) \mathrm{CaO} \cdot(\mathrm{y}-1) \mathrm{MgO}$. $\left.\mathrm{ZAl}_{2} \mathrm{O}_{3}\right)+[\mathrm{Mg}]$

When the outer surface has totally changed to $\mathrm{CaO}-\mathrm{Al}_{2} \mathrm{O}_{3}$ system, the reaction presents as the following equation. As the reaction proceeds, the outer surface transfers to liquid along with the path of $\mathrm{CaO} \cdot 6 \mathrm{Al}_{2} \mathrm{O}_{3} \rightarrow \mathrm{CaO} \cdot 2 \mathrm{Al}_{2} \mathrm{O}_{3} \rightarrow$ $\mathrm{CaO} \cdot \mathrm{Al}_{2} \mathrm{O}_{3} \rightarrow 12 \mathrm{CaO} \cdot 7 \mathrm{Al}_{2} \mathrm{O}_{3}$, and the inclusion morphology changes to spherical shape.

$[\mathrm{Ca}]+\left(\mathrm{xCaO} \cdot \mathrm{yAl}_{2} \mathrm{O}_{3}\right)=\left((\mathrm{x}+1) \mathrm{CaO} \cdot(\mathrm{y}-1 / 3) \mathrm{Al}_{2} \mathrm{O}_{3}\right)+2 / 3[\mathrm{Al}]$

There exists a concentration gradient of $\mathrm{CaO}$ and $\mathrm{MgO}$ in the outside layer, shown in Fig. 19, resulting in that the $\mathrm{Ca}^{2+}$ in the outer part with higher amount of $\mathrm{CaO}$ continues to diffuse toward the inner part containing lower $\mathrm{CaO}$, while $\mathrm{Mg}^{2+}$ diffuses from the inner part to the outer part. So inside 
the outer layer, there is a reaction expressed by Eq. (18):

$$
\begin{aligned}
& \mathrm{Ca}^{2+}+\left(\mathrm{xCaO} \cdot \mathrm{yMgO} \cdot \mathrm{zAl}_{2} \mathrm{O}_{3}\right)=((\mathrm{x}+1) \mathrm{CaO}(\mathrm{y}-1) \mathrm{MgO} \cdot \\
& \left.\mathrm{zAl}_{2} \mathrm{O}_{3}\right)+\mathrm{Mg}^{2+}
\end{aligned}
$$

On the interface between the outer layer and the $\mathrm{MgO} \cdot \mathrm{Al}_{2} \mathrm{O}_{3}$ core, the following reaction takes place:

$\mathrm{xCa}^{2+}+\left(\mathrm{yMgO} \cdot \mathrm{zAl}_{2} \mathrm{O}_{3}\right)=\left(\mathrm{xCaO}(\mathrm{y}-\mathrm{x}) \mathrm{MgO} \cdot \mathrm{zAl}_{2} \mathrm{O}_{3}\right)+\mathrm{xMg}^{2+}$

Besides, there also may be some [Ca] diffuses to the sur-

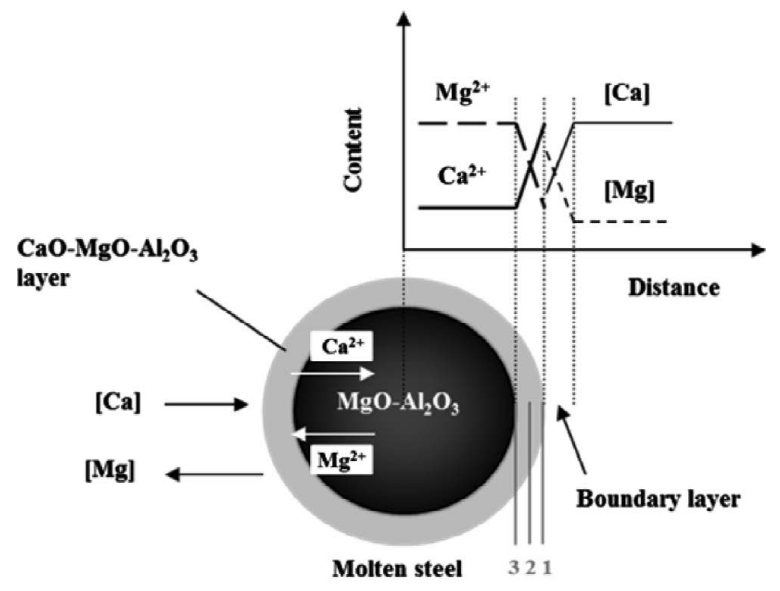

$1:[\mathrm{Ca}]+\left(\mathrm{xCaO} \cdot \mathrm{yMgO} \cdot \mathrm{zAl}_{2} \mathrm{O}_{3}\right)=\left((\mathrm{x}+1) \mathrm{CaO}(\mathrm{y}-1) \mathrm{MgO} \cdot \mathrm{zAl}_{2} \mathrm{O}_{3}\right)+[\mathrm{Mg}]$ 2: $\mathrm{Ca}^{2+}+\left(\mathrm{xCaO} \cdot \mathrm{yMgO} \cdot \mathrm{zAl}_{2} \mathrm{O}_{3}\right)=\left((\mathrm{x}+1) \mathrm{CaO}(\mathrm{y}-1) \mathrm{MgO} \cdot \mathrm{zAl}_{2} \mathrm{O}_{3}\right)+\mathrm{Mg}^{2+}$ $3: \mathrm{xCa}^{2+}+\left(\mathrm{yMgO} \cdot \mathrm{zAl}_{2} \mathrm{O}_{3}\right)=\left(\mathrm{xCaO}(\mathrm{y}-\mathrm{x}) \mathrm{MgO} \cdot \mathrm{zAl}_{2} \mathrm{O}_{3}\right)+\mathrm{xMg}^{2+}$

Fig. 18. Schematic for the modification of a $\mathrm{MgO} \cdot \mathrm{Al}_{2} \mathrm{O}_{3}$ inclusion.

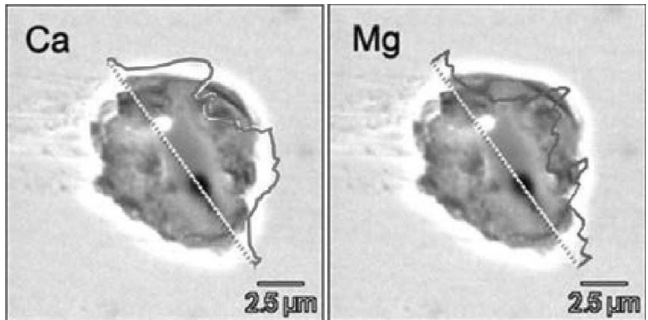

Fig. 19. Concentration gradient of $\mathrm{CaO}$ and $\mathrm{MgO}$ in a inclusion. face of $\mathrm{MgO} \cdot \mathrm{Al}_{2} \mathrm{O}_{3}$ core through the outer layer, and reacts with the core according to Eq. (15). By these reactions, the spinel type inclusion could finally changes to $\mathrm{xCaO} \cdot \mathrm{yMgO}$. $\mathrm{ZAl}_{2} \mathrm{O}_{3}$ type inclusion.

However, the modification effect depends on the size of initial spinel inclusion, as described elsewhere. ${ }^{14)}$ When the size is relatively large, the inclusion after calcium treatment may have a spherical calcium aluminate outer layer with an irregular spinel core. When the size is small, the time is long enough for the complete modification, consequently resulting in a spherical magnesium calcium aluminate with homogeneous distribution of elements in the inclusion.

As mentioned above, a large amount of $\mathrm{CaS}$ precipitated after calcium treatment which dramatically worsened the modification effect. There were three main $\mathrm{CaS}$ distribution types observed, including collision with oxide, surrounding oxide, and uniformly distributed within oxide, shown in Fig. 11. The possible formation mechanisms of the three types are illustrated in Fig. 20.

The type of collision with oxide mainly formed after calcium addition. The local high concentration of calcium in the melt (for example near the feeding point shown in Fig. 20 ) induced the precipitation of a large amount of solid $\mathrm{CaS}$ particles, which then collided with spinel or calcium aluminate inclusions, leaving the existence of morphology of collision with oxide. Another possible formation way of this type is that spinel or calcium aluminate particles acted as the nuclei of heterogeneous nucleation, and $\mathrm{CaS}$ precipitated on their surfaces without consuming $\mathrm{Ca}$ in the nucleus particles.

The type of surrounding oxide may be formed during the modification process of $\mathrm{MgO} \cdot \mathrm{Al}_{2} \mathrm{O}_{3}$ spinel or alumina to calcium aluminate. When the activity of $\mathrm{CaO}$ on the surface of calcium aluminate increases to a critical value, or as temperature decreasing, a layer of $\mathrm{CaS}$ precipitates on the particle surface according to Eq. (5). On one hand, the precipitation consumes $\mathrm{CaO}$ contained in the calcium aluminate. On the other hand, it hinders the diffusion of [Ca] in molten steel to calcium aluminate surface. These two aspects induce the lower $\mathrm{CaO}$ content in calcium aluminate, leading to the incompletely modification of inclusions.

The uniform distribution type may be formed by the precipitation of $\mathrm{CaS}$ dissolved in calcium aluminate during the temperature decreasing process. Calcium aluminate corresponds to a binary $\mathrm{CaO}-\mathrm{Al}_{2} \mathrm{O}_{3}$ slag, and the sulfide capacity

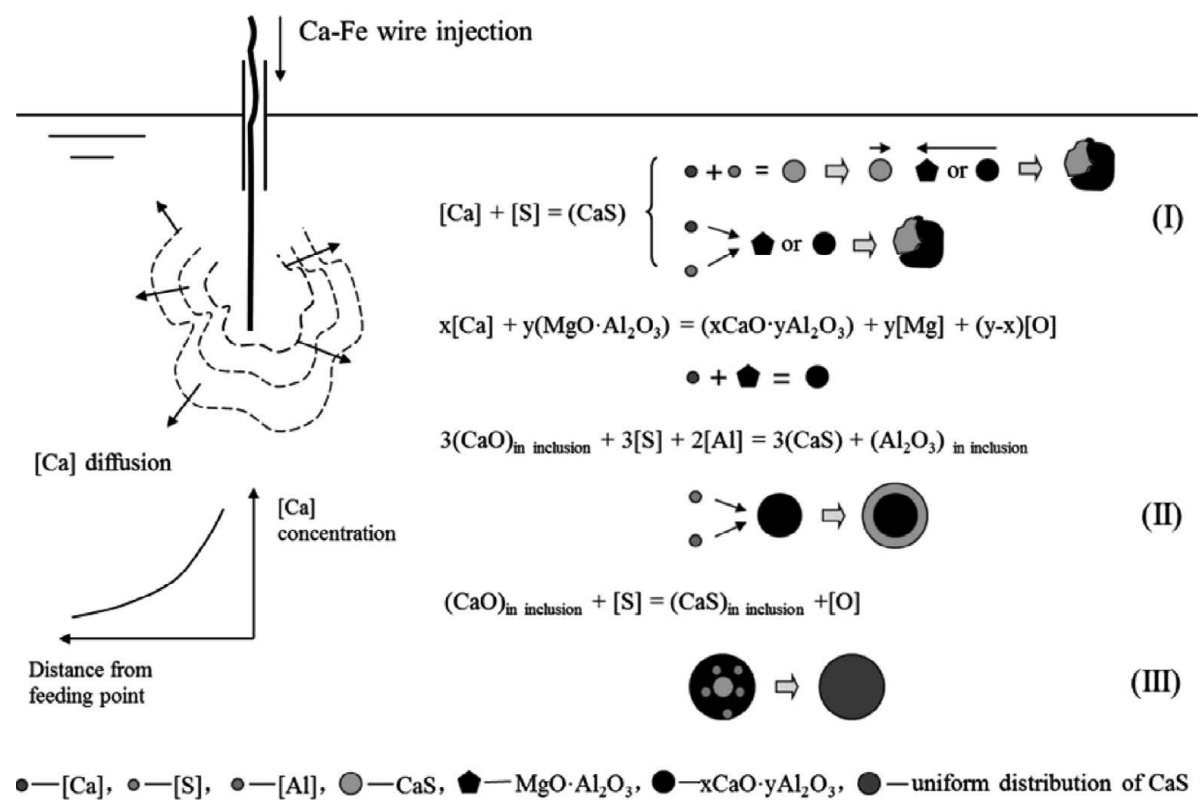

Fig. 20. Schematic for the formation of $\mathrm{CaS}$ with different distribution types. 
can be calculated by the optical basicity of slag. ${ }^{42)}$ The calculated sulfide capacity of $\mathrm{C}_{12} \mathrm{~A}_{7}$ is $0.035 \%$, and it was reported that the solubility of $\mathrm{CaS}$ in $\mathrm{C}_{12} \mathrm{~A}_{7}$ is about $3.3 \%$ at $1873 \mathrm{~K}^{37)}$ As temperature decreasing, CaS precipitates in calcium aluminate owing to the decreasing solubility of $\mathrm{CaS}$.

\section{Conclusions}

A plant trial of LCAK steel production was performed, and characteristics of inclusions during LF refining and calcium treatment were investigated. Thermodynamic equilibriums between $\mathrm{Mg}, \mathrm{Al}, \mathrm{O}$ as well as $\mathrm{MgO} \cdot \mathrm{Al}_{2} \mathrm{O}_{3}$ spinel and calcium-aluminate and calcium-sulfide formation were studied to understand the fundamentals of inclusion modification. Furthermore, the change mechanisms of oxide inclusion and calcium-sulfide precipitation were discussed. The following conclusions were obtained:

(1) Oxide inclusions almost changed along with the path of $\mathrm{Al}_{2} \mathrm{O}_{3} \rightarrow \mathrm{MgO} \cdot \mathrm{Al}_{2} \mathrm{O}_{3} \rightarrow(\mathrm{MgO} \cdot) \mathrm{CaO} \cdot \mathrm{Al}_{2} \mathrm{O}_{3}$ during $\mathrm{LF}$ refining and calcium treatment. However, it was a little different from the thermodynamic calculation. There were still many inclusions located out of the liquid region even though after calcium treatment owing to the initial large size of inclusions and the precipitation of a large amount of $\mathrm{CaS}$.

(2) There were three distribution types of CaS: collision with oxide, surrounding oxide, and uniformly distributed within oxide. The possible formation time of each type are after calcium addtion, during the modification process of $\mathrm{MgO} \cdot \mathrm{Al}_{2} \mathrm{O}_{3}$ spinel or alumina to calcium-aluminate, and during temperature decreasing process, respectively. The formation of $\mathrm{CaS}$ extremely worsened the modification effect of inclusions.

(3) The area fraction of inclusions is more suitable and accurate to characterize the amount of inclusions than the number density of inclusions. Ladle refining process efficiently decreased the amount of inclusions, while after calcium treatment, the amount of inclusions increased significantly, especially large inclusions.

(4) Based on the thermodynamic analysis, $\mathrm{MgO} \cdot \mathrm{Al}_{2} \mathrm{O}_{3}$ spinel inclusion is easy to form. It is estimated that only approximately $0.5 \mathrm{ppm}[\mathrm{Mg}]$ is needed when [Al] in steel is $0.04 \%$. With $7 \mathrm{ppm}[\mathrm{Mg}]$, the transformation from $\mathrm{MgO} \cdot \mathrm{Al}_{2} \mathrm{O}_{3}$ spinel to liquid calcium-aluminate could occur even if with only $2 \mathrm{ppm}$ calcium in the molten steel. However, more $[\mathrm{Mg}]$ and $[\mathrm{Ca}]$ contents are required in plant practice since the reactions are under non-equilibrium.

(5) The inclusions of $\mathrm{CaS}$ are undesirable in the LCAK steel. At equilibrium, when the sulfur is $0.0040 \%$, in order to prevent the direct precipitation of $\mathrm{CaS}$ at $1873 \mathrm{~K}$, the calcium should be less than $0.0048 \%$, while at $1823 \mathrm{~K}$ it should be less than $0.0019 \%$. Assuming that the [Al] is $0.03 \%-0.05 \%$, to prevent the precipitation of $\mathrm{CaS}$ on the surface of liquid calcium- aluminates, the [S] content should be less than $0.0073 \%-0.0052 \%$ at $1873 \mathrm{~K}$ and less than $0.0044 \%-0.0031 \%$ at $1823 \mathrm{~K}$.

\section{Acknowledgement}

The authors are grateful for support from the National Science Foundation China (Grant No. 51274034), the High Quality Steel Consortium at University of Science and Tech- nology Beijing (China), and Shougang Jingtang United Iron $\&$ Steel Co. (China) for industrial trials.

\section{REFERENCES}

1) C. Bonilla: Iron Steelmaker, 22 (1995), 41

K) Okohira, N. Sato and H. Mori: Trans. ISIJ, 14 (1974), 102.

3) S. Guomin, Z. Li, Z. Yiyu, Z. Jianjun, W. Wenjun, Z. Jiongming, W. Wanjun and W. Xinhua: Iron Steel (China), 35 (2000), 12

4) M. T. Burns, J. Schade and C. Newkirk: 74th Steelmaking Conf. Proc., ISS, Warrendale, PA, (1991), 513.

5) H. Matsuno, Y. Kikuchi, M. Komatsu, M. Arai, K. Watanabe and H. Nakashima: Iron Steelmaker, 20 (1993), 35.

6) Z. Qiyun, W. Yadong, L. Xifu and Z. Yudong: Steelmaking (China), 17 (2001), 11

7) L. Jiangong, Z. Zhao and L. Liangtian: Steelmaking (China), 15 (1999), 3.

8) X. Zhirong, Y. Wen, C. Jing and W. Xinhua: Iron Steel (China), 45 (2010), 33

9) W. Yang, J. Cao, X.-h. Wang, Z.-r. Xu and J. Yang: J. Iron Steel Res. Int., 18 (2011), 6.

10) L. Sun, L. Zhang, J. Li, Y. Chen and S. Yang: Iron Steel Tech., 9 (2012), 59 .

11) L. Zhang: J. Iron Steel Res. Int., 13 (2006), 1.

12) L. Zhang and B. G. Thomas: ISIJ Int., 43 (2003), 271.

13) L. Zhang and B. G. Thomas: Metall. Mater. Trans. B, 37 (2006), 733.

14) S. Yang, L. Zhang, J. Li and K. Peaslee: Metall. Mater. Trans. B, 43B (2012), 731

15) K. Larsen and R. J. Fruehan: Iron Steelmaker, 17 (1990), 45.

16) N. Verma, P. Pistorius, R. Fruehan, M. Potter, M. Lind and S. Story: Metall. Mater. Trans. B, 42 (2011), 711.

17) N. Verma, P. Pistorius, R. Fruehan, M. Potter, M. Lind and S. Story: Metall. Mater. Trans. B, 42 (2011), 720.

18) H. Itoh, M. Hino and S. Ban-ya: Tetsu-to-Hagané, 84 (1998), 85

19) M. Numata, Y. Higuchi and S. Fukagawa: Tetsu-to-Hagané, 84 (1998), 159.

20) M. Numata, Y. Higuchi and S. Fukagawa: Steelmaking Conf. Proc., ISS, Warrendale, PA, (1998), 215.

21) T. Ikeda, H. Ichihashi and N. Fujino: Tetsu-to-Hagané, 66 (1980), 2040.

22) D. Z. Lu, G. A. Irons and W. K. Lu: Ironmaking Steelmaking, 21 (1994), 362.

23) S. K. Choudhary and A. Ghosh: ISIJ Int., 48 (2008), 1552.

24) C. E. Cicutti, J. Madias and J. C. Gonzalez: Ironmaking Steelmaking, 24 (1997), 155.

25) G. Ye, P. Jonsson and T. Lund: ISIJ Int., 36 (1996), S105

26) Y. Higuchi, M. Numata, S. Fukagawa and K. Shinme: ISIJ Int., 36 (1996), S151.

27) P. J. Hyun, K. D. Sik and L. S. Beom: Metall. Mater. Trans. B, 36 (2005), 67.

28) H. Todoroki and K. Mizuno: Iron Steelmaker, 30 (2003), 60.

29) H. Itoh, M. Hino and S. Ban-ya: Tetsu-to-Hagané, 83 (1997), 773.

30) H. Itoh, M. Hino and S. Ban-ya: Tetsu-to-Hagané, 83 (1997), 695.

31) R. H. Rein and J. Chipman: Trans. Metall. Soc. AIME, 233 (1965), 415.

32) K. Nagata, J. Tanabe and K. S. Goto: Tetsu-to-Hagané, 75 (1989), 2023.

33) H. Itoh, M. Hino and S. Ban-ya: Metall. Mater. Trans. B, 28 (1997), 953.

34) H. Itoh, M. Hino and S. Ban-ya: Tetsu-to-Hagané, 83 (1997), 623.

35) H. Suito and R. Inoue: ISIJ Int., 36 (1996), 528

36) The Japan Society for the Promotion of Science, The 19th Committee on Steelmaking, Recommended Values of Equilibrium Constants for the Reactions in Steelmaking. JSPS, Tokyo, (1984).

37) B. Ozturk and E. T. Turkdogan: Metal. Sci., 18 (1984), 299.

38) K. Beskow, N. N. Tripathi, M. Nzotta, A. Sandberg and S. Du: VII Int. Conf. on Molten Slags Fluxes and Salts, The South African Institute of Mining and Metallurgy, South Africa, (2004),

39) D. K. Fisler and R. T. Cygan: Am. Mineral., 84 (1999), 1392.

40) T. LaTourrette and G. Wasserburg: Earth Planet. Sci. Lett., 158 (1998), 91

41) M. Morioka: Geochimica et Cosmochimica Acta, 45 (1981), 1573.

$42)$ R. W. Young, J. A. Duffy, G. J. Hassall and Z. Xu: Ironmaking Steelmaking, 119 (1992), 201. 